\title{
Iğdır İlinde Süt Sığırcılığı İşletmelerinde Buzağı Yetiştirme Üzerine Bir Araştırma
}

\author{
Volkan KAYLAN ${ }^{1}$ (i) İsa YILMAZ $^{2}$ (iD), Mete YANAR ${ }^{3}$ (D) \\ ${ }^{1}$ Zootekni Anabilim Dalı, Fen Bilimleri Enstitüsü, Iğdır Üniversitesi, Iğdır, 2Zootekni Bölümü, Ziraat Fakültesi, Iğdır Üniversitesi, Iğdır, \\ 3Zootekni Bölümü, Ziraat Fakültesi, Atatürk Üniversitesi, Erzurum \\ ${ }^{1}$ https://orcid.org/0000-0002-9115-4501, ${ }^{2}$ https://orcid.org/0000-0001-6796-577X, ${ }^{3}$ https://orcid.org/0000-0002-5311-5675 \\ 凶:dr.isayilmaz@gmail.com
}

\section{ÖZET}

$\mathrm{Bu}$ araştırmada, Iğdır ilinde sı̆̆ır yetiştiriciliği yapılan işletmelerde hayvanların üreme özellikleri ile buzağı yetiştirme uygulamaları incelenmiştir. Araştırmada 162 işletme sahibiyle yüz yüze anket yapılmıştır. İşletmelerin \%3.1'inde doğumdan sonra 30 dakika ve \%96.9'unda ise 60 dakika içi nde buzağıya ağız sütü içirdikleri tespit edilmiştir. Yetiştiricilerin göbek kordonu kesim ve bakımı yapma oranları sırasıyla \%14.2 ve \%85.8'dir. İşletmelerde ishal \%17.9, pnömoni \%17.9 ve ishal+pnömoni \%64.2 ile buzağlların sıklıkla ölümüne sebep olan hastalıklar olarak belirlenmiştir. İşletmelerin \%100.0'ünde kızgılık tespitinin yapıldığı ve kızgınlık tespitinden sonra işletmelerin \%71.3'ü 5 saat sonra, \%21.2'sı 8 saat sonra ve $\% 7.5$ 'inin ise 12 saat sonra tohumlama yaptırdığ belirlenmiştir. Yetiştiricilerin \%6.8'i ineklerini ilk kızgınlıkta, \%56.2'sinin 60 gün sonra, \%34.6'sının 90 gün sonra ve \%2.5'inin ise 120 gün sonra ineklerini tohumladıkları veya boğaya verdikleri belirlenmiştir. İşletmelerde \%75.3 oranında suni tohumla yapıldığı belirlenmiştir. İşletmelerde gebelik başına tohumlama sayısı \%32.5'inde $1 \mathrm{kez}$, $\% 49,4$ 'ünde 1-2 kez ve \%18.1'inde ise $2 \mathrm{kez}$ ve üzeri tohumlama yapıldığı belirlenmiştir $(\mathrm{P}>0.05)$.

\section{A Research on Calf Breeding in Cattle Farms in Iğdır Province}

\section{ABSTRACT}

In this research, reproductive characteristics of the cattle and calf rearing applications in cattle breeding enterprises in Igdir province were investigated. A questionnaire was applied to 162 enterprise owners in the study. While $3.1 \%$ of the enterprises applied colostrum feeding of calves within the first 30 minutes after the birth, remaining $96.9 \%$ of the enterprises applied within the first 60 minutes after the birth. The ratios of breeders cutting the umbilical cord and providing umbilical cord care were $14.2 \%$ and $85.8 \%$, respectively. Most common causes of calf deaths were expressed by $17.9 \%$ breeders as diarrhea and $17.9 \%$ of them as pneumonia. Also, $64.2 \%$ of the breeders reported diarrhea+pneumonia as the most common cause. Detection of estrus was carried out in all (100\%) enterprises. Cows were inseminated after 5 hours from the detection of estrus in $71.3 \%$ of the enterprises, while insemination takes place after 8 hours and 12 hours in $21.2 \%$ and $7.5 \%$ of the enterprises, respectively. Cows were given to mating or insemination in $6.8 \%$ of the enterprises cows at the first estrus, while 60 days after the first estrus in $56.2 \%$ of the enterprises, and after 90 days in $34.6 \%$ and after 120 days in $2.5 \%$. Overall, $75.3 \%$ of the breeders prefereed artificial insemination while the remaining $24.7 \%$ did not prefer artificial insemination. Number of insemination per pregnancy was determined as 1 in $32.5 \%$ of the enterprises, $1-2$ in $49.4 \%$ and more than 2 in $18.1 \%(\mathrm{P}>0.05)$.
Araştırma Makalesi

Makale Tarihçesi

Geliş Tarihi $\quad: 14.05 .2019$

Kabul Tarihi : $: 30.06 .2019$

Anahtar Kelimeler

Büyükbaş

Buzağı yetiştirme

Iğdır ili

\section{Research Article}

\section{Article History}

Received : 14.05 .2019

Accepted : $\quad$ 30.06.2019

Keywords

Dairy Cattle Breeding

Calf breeding

Iğdır province

To Cite : Kaylan V, Yılmaz İ, Yanar M 2019. Iğdır İlinde Süt Sığırcılı̆̆ı İşletmelerinde Buzağı Yetiştirme Üzerine Bir Araştırma. KSU Tarım ve Doğa Derg 22(Ek Sayı 1): 169-178. DOI: 10.18016/ksutarimdoga.vi.564820 


\section{GİISŞ}

Sığır yetiştiriciliğinde üreme ve süt verimi sığırcılığın en önemli parametreleri olup, hedef maksimum süt üretimi ile yılda bir yavru elde etmektir (Karakaş, 2002; Varışlı ve Akyol, 2018). Bu hedefe ulaşmak için sığır sürülerinde kızgınlıkların takibi ve uygun zamanda kızgin hayvanların tohumlanması esastır (Ata, 2013; Anonim, 2018a). Doğum sonrası yeni gebelik için anne hayvanın hazır olması ve yüksek döl tutma oranı için 60. günlerde meydana gelen kızgınlıklarda hayvanların tohumlanması gereklidir (Ata, 2013).

Siğgrccılık işletmelerinde karlılı̆̆ın ve sürdürülebilirliğin sağlanması (Hanoğlu, 2013) önce damızlıkların seçimi ve çiftleştirilmesiyle (Tüzemen ve ark., 2013) elde edilen buzağlların uygun bir yetiştirme programıyla yetiştirilmesine bağlıdır (Tüzemen ve Yanar, 2013; Kaygisız ve Sönmez, 2018). Yetiştiricilere yönelik eğitim ve bilgi takviyesiyle buzağı yetiştirme programlarının başarıyla uygulanması mümkündür (Köseman ve Şeker, 2016a).

Türkiye genelinde buzağı kayıplarının önemli bir nedeni yavru atmadan kaynaklandiğ 1 ve yavru atma büyükbaş hayvanlarda genellikle brucella kaynaklı meydana geldiğinden (Can, 2010), bu hastalığın kontrol altına alınması için iyi bir eradikasyon programı uygulaması (Benkirane, 2006) gereklidir. Bununla birlikte kontrollü olarak boğalardan elde edilen spermalarda suni tohumlama yönteminin kullanılması tercih edilmelidir (Anonim, 2016). Çünkü suni tohumlama doğal aşımla karşılaştırıldığında daha hızlı verim artışı (genetik kazanç) elde edilmesi, hastalık kontrolü sağlaması ve daha ekonomik olması gibi avantajlara sahiptir (Cirit ve ark., 2017).

Buzağı kayıplarının diğer önemli bir sebebi ise, neonatal buzağı ishalleri ve sepsis olup, günümüzde çok ciddi buzağı kayıplarına neden olmaktadır. Oluşan bu kayıplar neticesinde işletmeler ciddi zarar görmektedir. İshallerin oluşmasında birçok faktör rol oynamakta olup, bunların başında; olumsuz çevre faktörleri, zayıf immunite ve yetersiz kolostrum alınması, bakteriyel etkenler, viral ve paraziter patojenler gelmektedir (Akyüz ve ark., 2017).

Buzağılara kolostrumun zamanında verilmemesi ve doğum sonrası göbek kordonu bakımının yapılmaması gibi pek çok faktöründe ishal oluşumunda etkili olduğu bilinmektedir (Lorenz ve ark. 2011). Teknik sığır yetiştiriciliğinde, sütten kesimde belirli bir bilgi ve buna dayalı bazı ölçüler dikkate alınarak yapılmalıdır. Buzağıların hem yeterince yem tüketimi miktarını hem de cüsse büyüklüğünü sağlaması dikkate alarak sütten kesime karar vermelidir (Doğan, 2014).
Buzağıların doğumu müteakip, 24 saat içinde canlı ağırlıklarının \%10'u kadar kolostrum almaları gerekmekte olup, bu miktarın yarısını doğumu müteakip 6 saat içinde alması gerekir (Tüzemen ve Yanar 2013). Çünkü kolostrumdaki bağışıklık maddelerinin düzeyi doğumla birlikte hızla azalır. Bu kapsamda 30 dakika içerisinde almak en iyi olarak kabul edilirken, buzağı 6 saatlik yaşa ulaştığında kolostrumdaki İmmunoglobulinler'in \%66'sını emmiş duruma gelmektedir. Çünkü İmmunoglobulinler'in varlığı sütte \%6.0 iken, üçüncü sağımdan sonra \%0,2 seviyesine düşmektedir (Anonymous, 2019).

Günümüzde buzağı ölüm oranı artık refah düzeyi ve yönetim kalitesinin en önemli göstergesi olarak görülmektedir (Koyuncu ve Karaca, 2018). Sığır yetiştiriciliği yapılan işletmelerde sürünün devamlılığı, sağlıklı buzağı yetiştirme programındaki başarıya bağlıdır. Bu programı etkileyen pek çok faktör olmasına karşın, buzağının yüksek kaliteli kolostrumla yeterli düzeyde beslenebilmesi, sağlığı ve yaşama gücü üzerinde en önemli etmendir (Erdem ve Atasever, 2005). Kolostrumun buzağıyı hastalıklardan koruyacak kalitede oluşabilmesi annenin kuru dönemde dengeli ve yeterli beslenmesi ile sağlanacak konforlu bir ortamla mümkündür (Kaygisız ve Köse, 2007; Doğan, 2014; Anonim, 2018b).

$\mathrm{Bu}$ çalışma Iğdır ilinde sığır yetiştiriciliği yapılan işletmelerde buzağı yetiştiriciliğinde yapılan uygulamaları tespit etmek ve önerilerde bulunmak amacıyla yapılmıştır.

\section{MATERYAL ve METOD}

Araştırmanın materyalini, 2017 yılında, ön çalışma ile Iğdır Tarım ve Orman İl ve İlçe müdürlükleri dokümanları değerlendirilerek, Iğdır Merkez, Aralık, Karakoyunlu ve Tuzluca ilçelerinde faaliyet gösteren sığırcılık işletmelerinden rastgele seçilen 162 yetiştirici ile anket çalışması oluşturmaktadır.

Iğdır Tarım ve Orman İl ve İlçe Müdürlükleri kayıtlarından işletmeler belirlendikten sonra il merkezi ve 3 ilçedeki yetiştiriciler ile yüz yüze görüşülerek, anket uygulanmıştır. Anket formu tamamlandıktan sonra bilgiler, çiftçilerin beklentilerini karşılayıp karşılamadığı, işletme sahiplerinin yetiştiriciliği uygun yapıp yapmadığı, mevcut hayvanların damızlık üretiminde etkili olarak kullanılıp kullanılmadığı sorularına cevap aramaya olanak verecek biçimde değerlendirilmiştir.

Ayrıca işletme büyüklüklerinin ve ilçelerin etkileri hakkında fikir edinilmeye çalışılmıştır. Sonuçta büyükbaş sığır yetiştiriciliğinin etkileri ve başarının ne olduğu hakkında fikir yürütme imkânı elde edilmiştir. Bununla birlikte yetiştiricilerin hayvan bakım ve besleme ile yetiştiricilik uygulamaları hakkında bilgiler edinilmiştir. 
Araştırmada kullanılan anket sayısının tespitinde; Iğdır ilindeki toplam işletme sayısını gösteren $\mathrm{N}$ bilinmesine karşın, bölgede daha önce yeterli çalışma yapılmadığından standart sapma ve varyans değerleri bilinmediğinden, bu gibi durumlarda anket uygulanacak işletme sayısını belirlemek için kullanılan ve Basit Tesadüfi Örnekleme içerisinde yer alan ve ayrıntıları Yamane (2010) tarafindan açıklanan aşağıdaki eşitlik kullanılmıştır.

$$
n=\frac{N \cdot t^{2} p \cdot q}{(N-1) D^{2}+t^{2} p q}
$$

$\mathrm{n}=$ örnek sayısı

$\mathrm{N}=$ Küme büyüklüğü

$\mathrm{D}=$ Kabul edilen veya arzu edilen örnekleme hatası

$\mathrm{t}=$ Tablo değeri

$\mathrm{p}=$ Hesaplanması istenen oran $\mathrm{q}=1-\mathrm{p}$

$\mathrm{n}=\frac{8887 \cdot(1,96)^{2} \cdot(0,1) \cdot(0,9)}{(8887-1) \cdot(0,05)^{2}+(1,96)^{2} \cdot(0,1) \cdot(0,9)}=162$ örnek sayısı belirlenmiştir.

İstatistiksel değerlendirmelerde; elde edilen bilgiler excel programı yardımıyla düzenlenerek analize hazır hale getirilmişlerdir. Sayılarak iki boyutlu tablolarda özetlenebilen özellikler için bulgular sayı ve yüzdelik olarak ifade edilmiş ve analitik değerlendirmede $\chi^{2}$ testi kullanılmıştır (Yıldız ve ark., 2006).

\section{BULGULAR ve TARTISSMA}

Anket yapılan işletmelerde elde edilen verilerin değerlendirilmesiyle elde edilen sonuçlar aşağıda verilmiştir. $\mathrm{Bu}$ bağlamda yetiştiricilerin eğitim durumları Çizelge 1'de sunulmuştur.

Çizelge 1. Yetiştiricilerin eğitim durumları

\begin{tabular}{lllllllll}
\hline \multirow{2}{*}{ Iğdır İli } & \multicolumn{2}{l}{ Yetiştiricilerin Eğitim Durumlarl } & & & & & \multirow{2}{*}{ Toplam } \\
\cline { 3 - 9 } & & Yok & Okur-yazar & Ilkokul & Ortaokul & Lise & Ön lisans & \\
\multirow{2}{*}{ Genel } & $\mathrm{N}$ & 7 & 36 & 17 & 53 & 46 & 3 & 162 \\
& $\%$ & 4.3 & 22.2 & 10.5 & 32.7 & 28.4 & 1.9 & 100 \\
\hline
\end{tabular}

Genel olarak, yetiştiricilerin yüksek oranda \%32.7'nin Ortaokul düzeyinde, \%28.4 Lise ve \%1.9'unun ise Ön lisans mezunu oldukları belirlenmiştir. Ayrıca, Okuryazar (diploma yok) olan ve olmayan kişilerin oranı da sirasiyla \%22.2 ve \%4.3 olarak tespit edilmiştir. Okuma-yazma bilenlerin oranı Iğdır ilinde \%95.7 olarak belirlenmiştir (Çizelge 1).

Tatar (2007), Ankara ve Aksaray illerinde bulunan işletme sahiplerinin eğitimine ilişkin yaptığı çalışmada, Ankara'da yetiştiricilerin \%63’nün, Aksaray'da ise \%76'sının ilkokul mezunu olduğunu tespit etmiştir. Mundan ve ark. (2018), Şanlıurfa ilinde faaliyette bulunan süt sığırı işletmelerinde yetiştiricilerin \%31.71'inin ilkokul diplomasına sahip olduklarını belirlemişlerdir. Bu oran Iğdır ilinde \%10.5 seviyesinde olup, diğer yetiştiricilerin büyük çoğunluğu (\%32.7) ortaokul seviyesindedir. Iğdır ilinde yetiştiricilerin eğitim seviyesinin yüksek olduğu söylenebilir.

Tilki ve ark. (2013), Kars ilinde yaptıkları çalışmada eğitim düzeylerinin \%75 oranında ilk ve ortaokul düzeyinde olduğunu bildirmiş olup, Iğdır ilinde $\% 42.7$ olan ilk ve ortaokul düzeyindeki eğitimden farklılık göstermektedir.

Türkiye'de hayvancılık işletmelerinde mevcut çevre faktörleri, yüksek genetik yapıya sahip hayvanların yetiştiriciliğinin yapılmasına uygun değildir. Böylece, bu hayvanların genetik yapılarının izin verdiği veriminin ortaya çıkması olası değildir. Bu sebeple Türkiye'de hayvansal üretim seviyesinin artırılmasında çevre faktörlerinin iyileştirilmesi çok önemlidir (Tüzemen ve ark., 2013).

Çalışmada Iğdır ilinde sığır yetiştiriciliği işletmelerinde buzağıların beslenmeleri ve doğum sonrası ağız sütü tüketme durumları incelenmiş ve Çizelge 2'de özetlenmiştir.

Çizelge 2. İşletmelerde doğan buzağılara ağız sütü verme zamanı

\begin{tabular}{|c|c|c|c|c|}
\hline \multirow{2}{*}{ İlçeler } & & \multicolumn{2}{|c|}{ Ağız sütü verilme zamanı (dakika içinde) } & \multirow{2}{*}{ Toplam } \\
\hline & & 30 dakika içinde & 60 dakika içinde & \\
\hline \multirow{3}{*}{ Merkez } & $\mathrm{n}$ & 5 & 37 & 42 \\
\hline & $\%$ & 11.9 & 88.1 & 100.0 \\
\hline & $\mathrm{n}$ & 0 & 40 & 40 \\
\hline \multirow{2}{*}{ Karakoyunlu } & $\%$ & 0.0 & 100.0 & 100.0 \\
\hline & $\mathrm{n}$ & 0 & 40 & 40 \\
\hline \multirow{2}{*}{ Aralık } & $\%$ & 0.0 & 100.0 & 100.0 \\
\hline & $\mathrm{n}$ & 0 & 40 & 40 \\
\hline Tuzluca & $\%$ & 0.0 & 100.0 & 100.0 \\
\hline \multirow{2}{*}{ Genel } & $\mathrm{N}$ & 5 & 157 & 162 \\
\hline & $\%$ & 3.1 & 96.9 & 100.0 \\
\hline
\end{tabular}

$\chi^{2}=17.749 ; \mathrm{P}<0.05$ 
Çizelge 2 incelendiğinde, işletme sahiplerinin \%3.1'i doğumdan sonraki 30 dakika içinde, \%96.9'u ise 60 dakika içinde buzağıya ağız sütü içirdiklerini beyan etmişlerdir. Bu bulgular yetiştiricilerin ağız sütünün önemini kavradıkları ve ağız sütü içirilmesi konusunda bilgi sahibi ve farkındalıklarının olduğunu göstermektedir.

Diler ve ark. (2017), Erzurum ili Narman ilçe ve köylerinde 208 işletme sahibiyle yaptıkları çalışmada, işletmelerin \%47'sinde buzağılara ağız sütü verilmediğini, verilen işletmelerde ise buzağıların ağız sütünü annesini emerek (\%40) ya da biberonla (\%57) aldığını bildirmişlerdir. Ayrıca, yetiştiricilerin $\% 84$ 'ü üç günden daha az süreyle ağız sütü verdiklerini ifade ettiklerini bildirmişlerdir.

Anket sorularına cevap veren yetiştiricilerin buzağıları sütten kesme süreleri Çizelge 3'te özetlenmiştir. Süt içirme süreleri bakımından işletmeler arasında istatistiksel olarak bir farklılık tespit edilmemiştir $(\mathrm{P}>0.05)$.

Çizelge 3. Buzağıların işletmelerde sütten kesim zamanı

\begin{tabular}{llllll}
\hline \multirow{2}{*}{ İlçeler } & & \multicolumn{2}{l}{ Sütten kesim zamani (ay sonra) } & Toplam \\
\cline { 2 - 6 } & & 3 Ay sonra & 4 Ay sonra & 5 Ay sonra & 42 \\
\multirow{2}{*}{ Merkez } & $\mathrm{n}$ & 8 & 22 & 12 & 100.0 \\
& $\%$ & 19.0 & 52.4 & 28.6 & 40 \\
Karakoyunlu & $\mathrm{n}$ & 10 & 21 & 9 & 100.0 \\
& $\%$ & 25.0 & 52.5 & 22.5 & 40 \\
Aralık & $\mathrm{n}$ & 2 & 19 & 19 & 100.0 \\
& $\%$ & 5.0 & 47.5 & 47.5 & 40 \\
Tuzluca & $\mathrm{n}$ & 9 & 22 & 9 & 100.0 \\
\hline \multirow{2}{*}{ Genel } & $\%$ & 22.5 & 55.0 & 22.5 & 162 \\
& $\mathrm{~N}$ & 29 & 84 & 49 & 100.0 \\
\hline
\end{tabular}

$\chi^{2}=14.285 ; \mathrm{P}<0.05$

Yetiştircilerin buzağılara süt içirme süreleri hakkında verdikleri bilgilere göre (Çizelge 3) $\% 17.9$ 'unun 3 ay, \%51.9'unun 4 ay ve \%30.2'sinin 5 ay sonra buzağıları sütten kestikleri belirlenmiştir. $\mathrm{Bu}$ sonuçla buzağılara yeterince süt verildiği anlaşılmaktadır.

Erzurum ili Narman ilçe ve köylerinde 208 işletmede yapılan bir çalışmada, buzağılara normal süt verme sürelerinin çoğunlukla 4-5 (\%51) ay devam ettiği tespit edilmiştir (Diler ve ark., 2017). Mevcut araştırmada elde edilen bulgular bu çalışmada elde edilen bulgulara benzer bulunmuştur.
Akkuş (2009), Konya ilinde yapmış olduğu çalışmada sütten kesim yaşını ortalama 68.28 gün olarak bulmuştur. Iğdır ilinde işletmelerde sütten kesim süreleri daha uzun olduğundan bu çalışma sonuçlarından farklı bulunmuştur.

Sağlıklı buzağ önlemede ve azaltmada önemli bir husus doğumu takiben buzağılarda göbek kordonu bakımı yapmaktır. İşletme sahiplerinin yeni doğan buzağılarda göbek kordonu bakımı yapıp yapmadıkları sorgulanmış ve elde edilen bilgiler Çizelge 4'te özetlenmiştir.

Çizelge 4. Doğan buzağıların göbek kordonu bakımının yapılıp yapılmaması

\begin{tabular}{lllll}
\hline \multirow{2}{*}{ İçeler } & & \multicolumn{2}{l}{ Göbek kordonu bakımı yapılması } & Toplam \\
\cline { 2 - 5 } & & Evet & Hayır & 43 \\
Merkez & $\mathrm{n}$ & 9 & 78.6 & 100.0 \\
& $\%$ & 21.4 & 29 & 40 \\
Karakoyunlu & $\mathrm{n}$ & 11 & 72.5 & 100.0 \\
& $\%$ & 27.5 & 40 & 40 \\
Aralık & $\mathrm{n}$ & 0 & 100.0 & 100.0 \\
& $\%$ & 0.0 & 37 & 40 \\
Tuzluca & $\mathrm{n}$ & 3 & 92.5 & 100.0 \\
& $\%$ & 7.5 & 139 & 162 \\
\multirow{2}{*}{ Genel } & $\mathrm{N}$ & 23 & 85.8 & 100.0 \\
\hline
\end{tabular}

$\chi^{2}=15.705 ; \mathrm{P}<0.001$

Yetiştiriciler genelinde göbek kordonu kesim ve bakımı yapma oranı \%14.2 iken, yapılmama oranı \%85.8'dir. Bu bulgular işletme sahiplerinin göbek kordonu bakımının önemini yeterince kavrayamadıkları veya yetiştiricilerin bu konuyu önemsemediklerini göstermektedir. 
Koçyiğit ve ark. (2018), tarafindan Erzurum ili Narman İlçesi'ndeki sığırcılık işletmelerinin hayvan sağlığı, veteriner sağlık hizmetleri ve yetiştirici memnuniyeti ve beklentilerini araştırmak amacıyla 208 sığırcılık işletmesinde yaptıkları anket çalışmasında yetiştiricilerin \%26.6'ının doğum sonrası buzağılara göbek bakımı yaptırdıklarını belirlemişlerdir.

Aynı araştırıcılar tarafından Erzurum ili Hınıs ilçesinde 378 süt sığırı işletmesinde yapılan bir başka çalışmada (Koçyiğit ve ark., 2016) doğumdan sonra buzağılara göbek kordonu bakımı yapan işletmelerin oranının \%45 olduğunu belirlemişlerdir.

$\mathrm{Bu}$ çalışmada göbek kordonu bakımı yapan işletmelerin oranı (\%14.2) Erzurum ilinde yapılanlardan oldukça düşük bulunmuştur.

İşletmelerde doğum sonrası buzağı ölümlerinin zamana göre dağılımı yetiştirici bilgilerine göre düzenlenerek Çizelge 5'te verilmiştir. Elde edilen bilgilere göre işletmeler arasında buzağı ölüm zamanları konusunda önemli farklılıklar olduğu tespit edilmiştir $(\mathrm{P}<0.01)$.

Çizelge 5. İşletmelerde sıklıkla doğum sonrası buzağı ölüm zamanları

\begin{tabular}{|c|c|c|c|c|c|c|}
\hline \multirow{2}{*}{ İlçeler } & & \multicolumn{4}{|c|}{ Buzağı ölüm zamanları (gün içinde) } & \multirow{2}{*}{ Toplam } \\
\hline & & Ölüm yok & $0-30$ & $31-45$ & $46-60^{+}$ & \\
\hline \multirow{2}{*}{ Merkez } & $\mathrm{n}$ & 24 & 7 & 6 & 5 & 42 \\
\hline & $\%$ & 57.1 & 16.7 & 14.3 & 11.9 & 100.0 \\
\hline \multirow{2}{*}{ Karakoyunlu } & $\mathrm{n}$ & 15 & 7 & 10 & 8 & 40 \\
\hline & $\%$ & 37.5 & 17.5 & 25.0 & 20.0 & 100.0 \\
\hline \multirow{2}{*}{ Aralık } & $\mathrm{n}$ & 21 & 1 & 5 & 13 & 40 \\
\hline & $\%$ & 52.5 & 2.5 & 12.5 & 32.5 & 100.0 \\
\hline \multirow{2}{*}{ Tuzluca } & $\mathrm{n}$ & 21 & 0 & 3 & 16 & 40 \\
\hline & $\%$ & 52.5 & 0.0 & 7.5 & 40.0 & 100.0 \\
\hline \multirow{2}{*}{ Genel } & $\mathrm{N}$ & 81 & 15 & 24 & 42 & 162 \\
\hline & $\%$ & 50.0 & 9.3 & 14.8 & 25.9 & 100.0 \\
\hline
\end{tabular}

$\chi^{2}=32.974 ; \mathrm{P}<0.01$

Çizelge 5 incelendiğinde genellikle işletmelerin \%50'inde buzağı ölümlerinin görülmediği tespit edilirken, \%9.3’ünde 30 gün içinde, \%14.8'inde 45 gün içinde ve \%25.9'unda ise 60 gün içinde buzağ ölümleriyle karşılaştıkları belirlenmiştir.
Yine yetiştirici beyanlarına göre, yetiştiricilerin işletmelerinde en sık rastladıkları ve birincil problem olarak gördükleri ve buzağılarda ölümle sonuçlanan hastalıklarla ilgili verdikleri bilgiler Çizelge 6'da özetlenmiştir.

Çizelge 6. Yetiştiricilere göre üç önemli buzağı ölümüne sebep olan hastalık

\begin{tabular}{|c|c|c|c|c|c|}
\hline \multirow{2}{*}{ İlçeler } & & \multicolumn{3}{|c|}{ Buzağı ölüm sebepleri } & \multirow{2}{*}{-Toplam } \\
\hline & & $\overline{\text { İshal }}$ & Pnömoni & İshal + pnömoni & \\
\hline \multirow{2}{*}{ Merkez } & $\mathrm{n}$ & 19 & 12 & 11 & 42 \\
\hline & $\%$ & 45.3 & 28.6 & 26.2 & 100.0 \\
\hline \multirow{2}{*}{ Karakoyunlu } & $\mathrm{n}$ & 8 & 6 & 26 & 40 \\
\hline & $\%$ & 20.0 & 15.0 & 65.0 & 100.0 \\
\hline \multirow{2}{*}{ Aralık } & $\mathrm{n}$ & 2 & 5 & 33 & 40 \\
\hline & $\%$ & 5.0 & 12.5 & 82.5 & 100.0 \\
\hline \multirow{2}{*}{ Tuzluca } & $\mathrm{n}$ & 0 & 6 & 34 & 40 \\
\hline & $\%$ & 0.0 & 15.0 & 85.0 & 100.0 \\
\hline \multirow{2}{*}{ Genel } & $\mathrm{N}$ & 29 & 29 & 104 & 162 \\
\hline & $\%$ & 17.9 & 17.9 & 64.2 & 100.0 \\
\hline
\end{tabular}

$\chi^{2}=52.297 ; \mathrm{P}<0.05$

Cizelge 6 incelendiğinde, işletmelerde buzağıların ölümlerine sebep olan ve sıklıkla karşılaşılan hastalıklardan ishal \%17.9. pnömoni \%17.9 ve ishal + pnömoni \%64.2 ile buzağıların sıklıkla ölümüne sebep olan hastalıklar olarak belirtilmiştir.

Yılmaz (2005), tarafindan Erzurum ilinde kültür ırkı sığır yetiştiriciliği yapan tarım işletmelerinin yapısını ve kültür ırkı sığır yetiştiriciliğinin durumunu 
incelemek amacıyla yaptığı çalışmada, yetiştiricilerin \%75.9'unun buzağı ölümlerinin birincil nedeni olarak ishal+pnömoni olarak beyan ettiklerini bildirmiştir. $\mathrm{Bu}$ çalışmada ise, ishal+pnömoni den ölen buzağıların (\%58.0+\%17.9+\%17.9) oranını beyan eden işletmelerin oranı Erzurum ilinde elde edilen değerlerden yüksek bulunmuştur.

Donovan ve ark. (1998) 0-6 aylık buzağılarda genel mortalite oranını \%11.7 olarak bulmuşlar, bunun \%10'unun diyare'den, \%55.4'ünün pnömoni'den, \%21.9'unun septisemiden ve \% 11.8'inin ise diğer sebeplerden kaynaklandığını saptamışlardır. $\mathrm{Bu}$ veriler araştırmada tespit edilen ölüm sebepleri ile uyum göstermektedir.

Çalışmada yetiştiricilerin işletmelerinde kızgınlıkları takip etme durumu ve kızginlık tespiti sonrası tohumlama yapılma durumları için sorulara alınan cevaplar ayrı ayrı sayısal ve yüzdelik olarak Çizelge 7'de özetlenmiştir.

Çizelge 7. İneklerin kızgınlık tespiti ve tohumlama zamanları

\begin{tabular}{|c|c|c|c|c|c|c|}
\hline \multirow[t]{2}{*}{ İlçeler } & & \multirow{2}{*}{$\begin{array}{l}\text { Klzginlık tespiti } \\
\text { yapma } \\
\text { Evet }\end{array}$} & \multicolumn{3}{|c|}{$\begin{array}{l}\text { Kizgınlık sonrası tohumlama } \\
\text { zamanı (saat)* }\end{array}$} & \multirow[t]{2}{*}{ Toplam } \\
\hline & & & 5 saat sonra & 8 saat sonra & 12 saat sonra & \\
\hline \multirow{2}{*}{ Merkez } & $\mathrm{n}$ & 42 & 22 & 13 & 7 & (42) 42 \\
\hline & $\%$ & 100.0 & 52.4 & 31.0 & 16.7 & 100.0 \\
\hline \multirow{2}{*}{ Karakoyunlu } & $\mathrm{n}$ & 40 & 36 & 1 & 3 & (40) 40 \\
\hline & $\%$ & 100.0 & 90.0 & 2.5 & 7.5 & 100.0 \\
\hline \multirow{2}{*}{ Aralık } & $\mathrm{n}$ & 40 & 27 & 12 & 1 & (40) 40 \\
\hline & $\%$ & 100.0 & 67.5 & 30.0 & 2.5 & 100.0 \\
\hline \multirow{2}{*}{ Tuzluca } & $\mathrm{n}$ & 40 & 31 & 9 & 0 & (40) 40 \\
\hline & $\%$ & 100.0 & 77.5 & 22.5 & 0.0 & 100.0 \\
\hline \multirow{2}{*}{ Genel } & $\mathrm{N}$ & 161 & 116 & 35 & 11 & $(162) 162$ \\
\hline & $\%$ & 100.0 & 71.3 & 21.2 & 7.5 & 100.0 \\
\hline
\end{tabular}

$*: \chi^{2}=29.717 ; \mathrm{P}<0.001$

İşletmelerin \%100.0'ünde kızgılık tespitinin yapıldığg belirlenmiştir. Kızgınlıkların tespitinden sonra ineklerin $\% 71.3$ 'ü 5 saat sonra, \%21.2's 8 saat sonra ve \%7.5'inin ise 12 saat sonra kizginlık belirtisi gördükleri hayvanlarını tohumlamaktadırlar (Çizelge 7). Oniki saat sonra tohumlama yaptıran işletmelerin bilinçli olarak bu zamanı seçmeleri muhtemelen suni tohumlama yaptırdıklarının bir göstergesidir. Ancak, kızgınlığın görülmesini takiben kısa sürede ineklerin hemen tohumlanması hatalı bir uygulamadır. $\mathrm{Bu}$ konunun eğitim çalışmalarında yetiştiricilere özellikle vurgulanması gerekir. Iğdır ilinde yetiştiricilerin tamamına yakını bir hayvancılık organizasyonuna katıldıkları için eğitim almaları muhtemeldir.

Köseman ve ark., (2016b) Malatya ilindeki işletmelerde yapmış oldukları çalışmada \%63.8'inin kızgınlık tespiti yaptığını bildirmiş olup, Iğdır ilindeki üreticilerin daha yüksek oranda kızgınlık takibi yaptığı görülmüştür.

Araştırma kapsamında ele alınan işletmelerde, çiftçilerin ineklerini buzağılamayı takiben kaç gün sonra veya ne zaman tohumladıkları veya boğaya verdikleri de araştırılmış olup, elde edilen bilgiler Çizelge 8'de verilmiştir. Doğum sonrası ineklerin boğaya verilme zamanı konusunda işletmeler arasında bir farklılık tespit edilmemiştir ( $\mathrm{P}>0.05)$. Yani işletmelerde uygulamalar benzer şekilde yapılmaktadır.
Yetiştiricilerin \%6.8'inin ineklerini ilk kızgınlıkta, $\% 56.2$ 'sinin 60 gün sonra, \%34.6'sının 90 gün sonra ve $\% 2.5$ 'inin 120 gün sonra tohumladıkları veya boğaya verdikleri belirlenmiştir (Çizelge 8).

Diler ve ark. (2017), tarafından Narman ilçe ve köylerinde 208 işletmede yetiştiriciler ineklerin kızgınlıkta gösterdikleri tüm belirtileri (\%43) dikkate aldıkları ve yetiştiricilerin \%83’ünün doğum sonrası ilk kızginlıkta tohumlama yaptıklarını belirlemişlerdir. Iğdır ilinde ise, genellikle doğumdan 60 ve 90 gün sonra tohumlama yapıldığı belirlenmiştir.

Koçyiğit ve ark. (2015), Erzurum ilinde yapmış oldukları çalışmada, işletmelerin \%48'inin doğumdan 3 ay sonra ilk kızgınlıkta tohumlama yaptıklarını belirlemiş olup, İlimizdeki işletmelerde yapılan çalışma ile uyum göstermektedir.

İşletmelerde suni tohumlama yaptırılıp, yaptırılmama durumu incelendiğinde işletmelerde suni tohumlama yapıldığ 1 ve bu durumun işletmeler arasında istatistiki olarak $(\mathrm{P}<0.001)$ önemli olduğu tespit edilmiştir. Elde edilen bilgiler değerlendirilerek Çizelge 9'da verilmiştir.

$\mathrm{Bu}$ bilgilere göre (Çizelge 9), işletmelerde \%75.3 oranında suni tohumla yapıldığı ve $\% 24.7$ oranında ise tercih edilmediği belirlenmiştir. Yetiştiricilerin suni tohumlamayı tercih etmeme nedenlerini ise kendi içerisinde değerlendirildiğinde döl tutmama, 
tohumlama elemanı bulamama ve boğa var bilgilerinin oranları sirasiyla \%80.0. \%10.0 ve \%10.0 olarak belirlenmiştir.

Diler ve ark. (2017), tarafindan Narman ilçe ve köylerinde 208 işletme sahibiyle yapılan çalışmada, yetiştiricilerin \%66'sının hayvanlarına suni tohumlama yaptırdıklarını ve \%97'sinin bu uygulamadan memnun kaldıklarını bildirmişlerdir.
Modern sığır yetiştiriciliğinde genellikle yılda bir canlı yavru alınması hedeflenmektedir. Bu hedefe ulaşmak için işletmelerde bulunan hayvanların kızgınlıklarının takip edilip, zamanında tohumlanması esastır. Bu durum için işletmelerde gebelik başına tohumlama sayısı incelenmiş ve Çizelge 10'da verilmiştir.

Cizelge 8. Doğum sonrası ineklerin boğaya verilme zamanı

\begin{tabular}{|c|c|c|c|c|c|c|}
\hline \multirow{2}{*}{ İlçeler } & & \multicolumn{4}{|c|}{ Doğum sonrası boğaya verme zamanı (gün sonra) } & \multirow{2}{*}{ Toplam } \\
\hline & & İlk kızgınlıkta & 60 gün sonra & 90 gün sonra & 120 gün sonra & \\
\hline \multirow[b]{2}{*}{ Merkez } & $\mathrm{n}$ & 4 & 24 & 13 & 3 & 42 \\
\hline & $\%$ & 9.5 & 57.1 & 26.2 & 7.1 & 100.0 \\
\hline \multirow{2}{*}{ Karakoyunlu } & $\mathrm{n}$ & 3 & 21 & 15 & 1 & 40 \\
\hline & $\%$ & 7.5 & 52.5 & 37.5 & 2.5 & 100.0 \\
\hline \multirow{2}{*}{ Aralık } & $\mathrm{n}$ & 4 & 22 & 14 & 0 & 40 \\
\hline & $\%$ & 10.0 & 55.0 & 35.0 & 0.0 & 100.0 \\
\hline \multirow{2}{*}{ Tuzluca } & $\mathrm{n}$ & 0 & 24 & 16 & 0 & 40 \\
\hline & $\%$ & 0.0 & 60.0 & 40.0 & 0.0 & 100.0 \\
\hline \multirow{2}{*}{ Genel } & $\mathrm{N}$ & 11 & 91 & 56 & 4 & 162 \\
\hline & $\%$ & 6.8 & 56.2 & 34.6 & 2.5 & 100.0 \\
\hline
\end{tabular}

$\chi^{2}=18.370 ; \mathrm{P}<0.05$

Çizelge 9. İşletmelerde sun'i tohumlama yapılma durumu

\begin{tabular}{|c|c|c|c|c|c|c|c|}
\hline \multirow[b]{2}{*}{ İlçeler } & & \multicolumn{2}{|c|}{ Suni tohumlama ${ }^{1}$} & \multicolumn{3}{|c|}{ Hayır nedenleri ${ }^{2}$} & \multirow[b]{2}{*}{ Toplam } \\
\hline & & Evet & Hayır & $\begin{array}{l}\text { Döl } \\
\text { tutmama }\end{array}$ & $\begin{array}{l}\text { Tohumlamac1 } \\
\text { yok }\end{array}$ & $\begin{array}{l}\text { Boğa } \\
\text { var }\end{array}$ & \\
\hline \multirow{2}{*}{ Merkez } & $\mathrm{n}$ & 26 & 16 & 9 & 3 & 4 & (16) 42 \\
\hline & $\%$ & 61.9 & 38.1 & 56.3 & 18.8 & 25.0 & 100.0 \\
\hline \multirow{2}{*}{ Karakoyunlu } & $\mathrm{n}$ & 39 & 1 & 1 & 0 & 0 & (1) 40 \\
\hline & $\%$ & 97.5 & 2.5 & 100.0 & 0.0 & 0.0 & 100.0 \\
\hline \multirow{2}{*}{ Aralık } & $\mathrm{n}$ & 28 & 12 & 12 & 0 & 0 & (12) 40 \\
\hline & $\%$ & 70.0 & 30.0 & 100.0 & 0.0 & 0.0 & 100.0 \\
\hline \multirow{2}{*}{ Tuzluca } & $\mathrm{n}$ & 29 & 11 & 10 & 1 & 0 & (11) 40 \\
\hline & $\%$ & 72.5 & 27.5 & 90.9 & 9.1 & 0.0 & 100.0 \\
\hline \multirow{2}{*}{ Genel } & $\mathrm{N}$ & 122 & 40 & 32 & 4 & 4 & (40) 162 \\
\hline & $\%$ & 75.3 & 24.7 & 80.0 & 10.0 & 10.0 & 100.0 \\
\hline
\end{tabular}

$1: \chi^{2}=26.633 ; \mathrm{P}<0.001 .2: \chi^{2}=29.700 ; \mathrm{P}<0.01$

Çizelge 10. İşletmelerde gebelik başına tohumlama sayısı

\begin{tabular}{llllll}
\hline \multirow{2}{*}{ İlçeler } & \multicolumn{6}{c}{ Gebelik başına tohumlama sayısı (kez) } & Toplam \\
\cline { 3 - 7 } & & $\mathbf{1 ~ k e z}$ & $\mathbf{1 - 2}$ kez & 2 kez+ üzeri & 42 \\
Merkez & $\mathrm{n}$ & 16 & 17 & 9 & 100.0 \\
& $\%$ & 38.1 & 40.5 & 21.4 & 38 \\
Karakoyunlu & $\mathrm{n}$ & 9 & 22 & 7 & 100.0 \\
& $\%$ & 23.3 & 57.9 & 18.4 & 40 \\
Aralık & $\mathrm{n}$ & 15 & 20 & 5 & 100.0 \\
& $\%$ & 37.5 & 50.0 & 12.5 & 40 \\
Tuzluca & $\mathrm{n}$ & 12 & 20 & 8 & 100.0 \\
\hline \multirow{2}{*}{ Genel } & $\%$ & 30.0 & 50.0 & 20.0 & 160 \\
& $\mathrm{~N}$ & 52 & 79 & 29 & 100.0 \\
\hline
\end{tabular}

$\chi^{2}=12.307 ; \mathrm{P}>0.05$ 
Çizelge 10 incelendiğinde genel olarak işletmelerde gebelik başına tohumlama sayısı \%32.5'inde $1 \mathrm{kez}$, $\% 49.4$ 'ünde 1-2 kez ve \%18.1'inde ise $2 \mathrm{kez}$ ve üzeri tohumlama yapıldığı belirlenmiştir. $\mathrm{Bu}$ oranlar işletmeler arasında önemli bir farklılık oluşturmamiştır $(\mathrm{P}>0.05)$.

Elazı ̆ ilinde yetiştirilen Doğu Anadolu Kırmızısı (DAK) 81 baş inekte yapılan bir çalışmada gebelik için tohumlama sayısının ortalama 1.97 olduğu belirlenmiştir (Yıldız ve ark.,2008). Bu çalışmada da yaklaşık gebelik başına tohumlama sayısının büyük çoğunluğunun 1-2 kez olarak belirlenmiştir. Elazığ ilinde yapılan çalışma ile gebelik başına tohumlama sayısı bakımından benzer bulunmuştur.

Yavru atma sığır işletmelerinde görülen bir durumdur. Hayvanların yavru atmaları hastalıktan kaynaklanacağı gibi farklı sebeplerden dolayı da meydana gelebilmektedir. Yavru atma birçok nedene bağlı olarak gerçekleşebilmektedir. Bunlar arasında hayvanın sıkışması, bir yere çarpması, yetersiz beslenmesi, zehirlenmesi, küflü yiyecekler ve döl tutmama hastalıkları gibi nedenleri siralamak mümkündür. Özellikle gebeliğin beşinci ayından önce olan yavru atmalar brucella hastalığından kaynaklanmamaktadır. Ancak, gebeliğin 5. ayından sonra olan yavru atmalar Brucella ve diğer yavru atma sebepleri ile karışmaktadır. Bunu anlamanın yolu marazi maddelerin tahlil edilmesi sonucu anlaşılmaktadır. Yetiştiricilerin işletmelerinde yavru atma zamanları incelenmiş elde edilen veriler değerlendirilerek, Çizelge 11'de verilmiştir. Yavru atma zamanları bakımından işletmeler incelendiğinde istatistiksel olarak aralarında farlılıkların çok önemli olduğu belirlenmiştir $(\mathrm{P}<0.01)$

Çizelge 11 incelendiğinde işletmelerin \%27.2'sinde yavru atma olayının olmadığı beyan edilirken, \%13.0'ının gebeliğin 5. ayından önce, \% 59.9'unda ise gebeliğin 5. Ayından sonra meydana gelmiştir. Buna göre, yavru atma olayının büyük çoğunluğunun brucella hastalığından kaynaklandığı söylenebilir.

Çizelge 11. İşletmelerde görülen yavru atma zamanları

\begin{tabular}{|c|c|c|c|c|c|}
\hline \multirow{2}{*}{ İlçeler } & & \multirow{2}{*}{ Yavru atma yok } & \multicolumn{2}{|c|}{ Yavru atma zamanları gebeliğin } & \multirow{2}{*}{-Toplam } \\
\hline & & & 5. avından önce & 5. avından sonra & \\
\hline \multirow{2}{*}{ Merkez } & $\mathrm{n}$ & 20 & 7 & 15 & 42 \\
\hline & $\%$ & 47.6 & 16.7 & 35.7 & 100.0 \\
\hline \multirow{2}{*}{ Karakoyunlu } & $\mathrm{n}$ & 12 & 4 & 24 & 40 \\
\hline & $\%$ & 30.0 & 10.0 & 60.0 & 100.0 \\
\hline \multirow{2}{*}{ Aralık } & $\mathrm{n}$ & 8 & 5 & 27 & 40 \\
\hline & $\%$ & 20.0 & 12.5 & 67.5 & 100.0 \\
\hline \multirow{2}{*}{ Tuzluca } & $\mathrm{n}$ & 4 & 5 & 31 & 40 \\
\hline & $\%$ & 10.0 & 12.5 & 77.5 & 100.0 \\
\hline \multirow{2}{*}{ Genel } & $\mathrm{N}$ & 44 & 21 & 97 & 162 \\
\hline & $\%$ & 27.2 & 13.0 & 59.9 & 100.0 \\
\hline
\end{tabular}

$\chi^{2}=18.970 ; \mathrm{P}<0.01$

\section{SONUÇ ve ÖNERILER}

Iğdır ilinde büyükbaş hayvan yetiştiren işletme sahipleri ile yapilan anket sonucu edinilen bilgiler genel olarak değerlendirildiğinde; Yetiştiricilerin buzağı bakım ve besleme konusunda yeterli bilince sahip oldukları belirlenmiştir. Aynı şekilde yetiştiricilerin (\%88.4) kızgllık tespitini yapabildikleri, kızgınlığa göre zamanında tohumlama yaptıkları ve doğum sonrası boğaya verme zamanları konusunda yeterli bilgiye sahip olma durumları Iğdır ilinde süt ve besi sığırcılığının yaygınlaştırılması için bir avantaj olarak değerlendirilmelidir.

\section{TEŞEKKÜR}

$\mathrm{Bu}$ çalışma, birinci yazarın "Iğdır İlinde Büyükbaş Hayvan Yetiştiriciliğinin Yapısal Özellikleri” başlıklı Yüksek Lisans tezinin bir bölümünden özetlenerek hazırlanmıştır. Emeği geçen kişilere teşekkürü bir borç biliriz.

\section{KAYNAKÇA}

Akkuş Z 2009. Konya İlindeki Süt Sığırcıllı̆̆ı İşletmelerinin Yapısal Özellikleri. Selçuk Üniversitesi Fen Bilimleri Enstitüsü, Yüksek Lisans Tezi, 43s.

Akyüz E, Naseri A, Erkılıç EE, Makav M, Uzlu E, Kırmızıgül AH, Gökçe G 2017. Neonatal Buzağı İshalleri ve Sepsis. Kafkas Üniversitesi Fen Bilimleri Enstitüsü Dergisi 10 (2): 181-191.

Anonim 2016. Evcil Hayvanlarda Suni Tohumlama. Milli Eğitim Bakanlığı Yayınları, Ankara, $71 \mathrm{~s}$.

Anonim 2018a. Buzağ $\breve{1}_{1}$ Yetiştiriciliğinde Temel Sağlık İlkeleri ve Sürü Yönetimi Programı. Tarım İşletmeleri Genel Müdürlüğü Yayın No: 1, ISBN: 978-605-2207-04-8, Ankara, $154 \mathrm{~s}$. 
Anonim 2018b. Buzağı Yetiştiriciliğinde Temel Sağlık ilkeleri ve sürü yönetimi programı. Tarım İşletmeleri Genel Müdürlüğü. TíGEM, $153 \mathrm{~s}$.

Anonymous 2019. Heifer Raising-Birth to Weaning Importance of Colostrum Feeding. https://kb.wisc.edu/images/group226/52745/de_28.e n.pdf, (Erişim tarihi: 05.05.2019).

Ata A 2013. Sütçü Sığırlarda Döl Verimi Ölçütlerinin Güncel Yorumu. MAKÜ Sag. Bil. Enst. Derg., 1 (1): 30-41.

Benkirane, A., 2006. Ovine and caprine brucellosis: World distribution and control/eradication strategies in West Asia/North Africa region, Small Ruminant Research, 62(1):19-25.

Can MF 2010. Türkiye'de Brusella Abortus ve Brusella Melitensis Enfeksiyonlarından Kaynaklanan Finansal Kayılar ve Alternatif Brusella Kontrol Stratejilerinin Maliyet-Fayda Analizi. Ankara Üniversitesi Sağlık Bilimleri Enstitüsü, Doktora Tezi, 136 s.

Cirit Ü, Özmen MF, Ak K 2017. Suni Tohumlamanın Başarısını Etkileyen Faktörler, Sahada Tohumlama Uygulamalarında Sıkça Yapılan Hatalar ve Çözüm Önerileri. Türkiye Klinikleri Dölerme ve Suni Tohumlama-Özel Konular. 3(1):30-43.

Diler A, Güler O, Aydın R, Yanar M, Koçyiğit R 2017. Erzurum İli Narman İlçesi Sığırcılık İşletmelerinde Ciftlik Yönetimi ve Buzağı Yetiştirme Uygulamaları. Alınteri Zirai Bilimler Dergisi, 32(1):39-45.

Doğan Z 2014. Siyah-Alaca Buzağılarda Farklı Sütten Kesme Yaşının Büyüme Performansı Üzerine Etkileri. Adnan Menderes Üniversitesi Fen Bilimleri Enstitüsü, Zootekni Anabilim Dalı, Yüksek Lisans Tezi, $52 \mathrm{~s}$.

Donovan GA, Dohoo IR, Montgomery DM, Bennett FL, (1998). Associations between Passive Immunity and Morbidity and Mortality in Dairy Heifers in Florida. USA. Preventive Veterinary Medicine, 34: 31-46.

Erdem H, Atasever S. 2005. Yeni Doğan Buzağılarda Kolostrumun Önemi. OMÜ Ziraat Fakültesi Dergisi, 20(2):79-84.

Hanoğlu H 2013. Organik Tarım Mevzuatına Göre Türkiye'de Büyükbaş ve Küçükbaş Hayvan Yetiştiriciliği. Tarım Ekonomisi Dergisi, 19(1): 2734.

Karakaş E, 2002. Bursa-Yenişehir İlçesinde Yetiştirilen Holştayn Buzağıların Doğum Ağırlığı Sütten Kesim Yaşı, Süt Tüketimleri ve Yaşama Güçleri. Uludağ Üniversitesi Veteriner Fakültesi Dergisi, 21(1-2- 3):77-81

Kaygisız A Köse M 2007. Siyah Alaca İneklerde Kolostrum Kalitesi ve Kolostrum Kalitesinin Buzag1 Gelisme Özelliklerine Etkisi. Tarım Bilimleri Dergisi 13(4) : 321-325.

Kaygisız A, Sönmez E 2018. Süt Emme Döneminde
Uygulanan Farklı Besleme Yöntemlerinin Siyah Alaca Buzağıların Gelişim Performansı ve Bazı Kan Parametreleri Üzerine Etkisi KSÜ Tarım ve Doğa Dergisi 21(5):757-764.

Koçyiğit R, Aydın R, Diler A 2015. Erzurum İli Büyükbaş Hayvancılığının Durumu ve Gelişmesine Yönelik Öneriler. Alınteri Zirai Bilimler Dergisi, 29(2):34-46.

Koçyiğit R, Diler A, Yanar M, Güler O, Aydın R, Avcı M 2016. Süt Sığırcılığı İşletmelerinde Hayvan Sağlığı, Veteriner Sağlık Hizmetleri ve Yetiştirici Memnuniyeti, Erzurum İli Hınıs İlçesi Örneği. Türk Tarım ve Doğa Bilimleri Dergisi 3(1):24-32.

Koçyiğit R, Yanar M, Aydın R, Diler A, Güler O 2018. Sığırcılık İşletmelerinde Hayvan Sağlığı, Veteriner Sağllk Hizmetleri ve Yetiştirici Memnuniyeti ve Beklentileri, Erzurum İli Narman İlçesi Örneği. Kahramanmaraş Sütçü İmam Üniversitesi Tarım ve Doğa Dergisi, 21(2):203-208.

Koyuncu M, Karaca M.2018. Buzağılarda Yaşama Gücünün Anahtarı "Kolostrum", J. Anim. Prod., 59(1):67-78.

Köseman A, Şeker İ. 2016a. Malatya İlinde Sığgrcılık İsletmelerinin Mevcut Durumu: I. Yapısal Özellikler. F. Ü. Sağ. Bil. Vet. Derg. 9 (2): 61-69.

Köseman A, Rişvanlı A, Kaygusuzoğlu E, Saat N, Korkmaz H, Şeker İ 2016b. Malatya İlindeki Süt Suğırcılık İşletmelerinde Yetiştiricilerin Demografik Özellikleri ve İşletmedeki Üreme, Sürü Sağlığı ve Hijyen Konularında Bilgi Düzeylerinin Belirlenmesi. Eurasian J. Vet. Sci., 32( 2):101-108

Lorenz I, Fagan J, More SJ, 2011. Calf Health From Birth to Weaning. II. Management of Diarrhoea in Pre-weaned Calves. Irish Vet. J., 64 (9):1-6.

Mundan D, Atalar B, Meral BA, Yakışan MM 2018. Modern Süt Siğırı İşletmelerinin Yapısal ve Teknik Özelliklerinin Belirlenmesi Üzerine Bir Araştırma. Atatürk Üniversitesi Veteriner Bilimleri Dergisi, 13(2):201-210.

Tatar AM 2007. Ankara ve Aksaray Damızlık Sığır Yetiştiricileri İl Birliklerine Üye Süt Sığırcılığı İşletmelerinin Yapısı ve Sorunları. Ankara Üniversitesi Fen Bilimleri Enstitüsü, Zootekni ABD., 119s.

Tilki M, Sarı M, Aydın E, Işıł S, Aksoy AR 2013. Kars İli Sığır İşletmelerinde Barınakların Mevcut Durumu ve Yetiştirici Talepleri, I. Mevcut Durum. Kafkas Üniv.Vet. Fak. Dergisi, 19(1):109-116.

Tüzemen N, Yanar M, Akbulut Ö 2013. Hayvan Islahı Kitabı. Atatürk Üniversitesi Ziraat Fakültesi Ders Yayınları No:230, Atatürk Üniversitesi Ziraat Fakültesi Ofset Tesisi, Erzurum. 120s.

Tüzemen N, Yanar M. 2013. Buzağı Yetiştirme Teknikleri Kitabı. Atatürk Üniversitesi Ziraat Fakültesi Ders Yayınları No: 232, Erzurum, 266 s.

Varışlı Ö, Akyol N 2018. Süt Sığırcılığında Üreme Verimini Etkileyen Faktörler Lalahan Hay. Araşt. 
Enst. Derg. 58 (Özel Sayl) 1-6.

Yamane T 2010. Temel Örnekleme Yöntemleri Kitabı. ISBN：978-975-8431-34-2, Literatür Yayıncıllk, İstanbul, 528s.

Yıldız N, Akbulut Ö, Bircan H 2006. İstatistiğe Giriş Kitabı. Uygulamalı Temel Bilgiler. Aktif Yayınevi, Erzurum, 350s.

Yıldız N, Aygen S, Özçelik M 2008. Elazı̆̆ Koşullarında Yetiştirilen Doğu Anadolu Kırmızısı
(DAK) İneklerde Süt, Döl Verimi ve Beden Ölçüleri. Fırat Üniversitesi Sağlık Bilimlileri Dergisi, 22(5):261-266.

Yılmaz İ 2005. Erzurum İlinde Farklı Kaynaklardan Getirilen Kültür Irkı Sığırlarla Yapılan Yetiştiriciliğin Analizi. Atatürk Üniversitesi Fen Bilimleri Enstitüsü, Zootekni ABD, Doktora Tezi, Erzurum, 137s. 